\title{
O CINEMA E O ENSINO DE CIÊNCIAS: UMA SEQUÊNCIA DIDÁTICA SOBRE CLONAGEM
}

\author{
THE CINEMA AND THE TEACHING OF SCIENCES: A DIDACTIC SEQUENCE ABOUT CLONING \\ EL CINE Y LA ENSEÑANZA DE CIENCIAS: UNA SECUENCIA DIDÁCTICA SOBRE CLONACIÓN
}

\author{
Vinicius Trindade Maciel \\ Universidade Federal de Goiás, UFG. E-mail: viniciuskakaroto20@gmail.com \\ Iara Lucia Barbosa Fernandes Vieira \\ Colégio da Polícia Militar Waldemar Mundin - SEDUCE/GO. E-mail: iarabioufg@gmail.com \\ Simone Sendin Moreira Guimarães \\ Universidade Federal de Goiás, UFG. E-mail: sisendin@gmail.com \\ Agência de fomento: CAPES.
}

\begin{abstract}
RESUMO
Para valorizar a formação de professores foi criado pelo governo federal em 2007 o PIBID (Programa Institucional de bolsas de Iniciação à Docência). Uma das áreas contempladas pelo programa é a biologia. $\mathrm{O}$ artigo aqui apresentado objetiva socializar e discutir criticamente uma sequência didática elaborada e desenvolvida no contexto do PIBID Biologia de uma universidade pública do estado de Goiás que utilizou o cinema (filmes comerciais) e a história e filosofia da ciência (HFC) para problematizar o tema clonagem (em especial a clonagem humana). A atividade foi desenvolvida no $1^{\circ}$ ano do Ensino Médio de uma escola pública de gestão militarizada. As considerações tanto para formação de professores via PIBID quanto para o ensino de biologia no ensino médio são positivas. Na formação oportunizou a criação e desenvolvimento de uma proposta crítica, que contextualiza histórica e socialmente a ciência. No ensino possibilitou o aprendizado tanto de elementos conceituais (célula, clonagem, bioética, biodireito, etc) quanto atitudinais (respeito, organização, etc) e procedimentais (realizar uma pesquisa, construir argumentos, etc) de maneira mais participativa.
\end{abstract}

PALAVRAS-CHAVE: Ensino de Biologia. PIBID. História da Ciência. Clonagem.

\section{ABSTRACT}

In order to value teacher education, the PIBID (Institutional Scholarship Initiative Program) was created by the federal government in 2007. One of the areas covered by the program is biology. The article presented here aims to socialize and critically discuss a didactic sequence elaborated and developed in the context of PIBID Biology of a public university in the state of Goiás that used cinema (commercial films) and history and philosophy of science (HFC) to problematize the theme cloning (in particular human cloning). The activity was developed in the 1st year of high school of a public school of militarized management. The considerations for both teacher training via PIBID and biology teaching in high school are positive. In the training, he facilitated the creation and development of a critical proposal that historically and socially contextualizes science. In teaching, it enabled the learning of conceptual elements (cell, cloning, bioethics, bio-law, etc.) as well as attitudinal (respect, organization, etc.) and procedural (research, construct arguments, etc.) in a more participative way.

KEYWORDS: Teaching of Biology. PIBID. History of Science. Cloning.

\section{RESUMEN}

Para valorar la formación de profesores fue creado por el gobierno federal en 2007 el PIBID (Programa Institucional de becas de Iniciación a la Docencia). Una de las áreas contempladas por el programa es la biología. El artículo aquí presentado objetiva socializar y discutir críticamente una secuencia didáctica 
elaborada y desarrollada en el contexto del PIBID. Biología de una universidad pública del estado de Goiás que utilizó el cine (películas comerciales) y la historia y filosofía de la ciencia (HFC) para problematizar el tema clonación (en particular la clonación humana). La actividad fue desarrollada en el primer año de la Enseñanza Media de una escuela pública de gestión militarizada. Las consideraciones tanto para la formación de profesores a través del PIBID como para la enseñanza de la biología en la enseñanza media son positivas. En la formación oportunizó la creación y desarrollo de una propuesta crítica, que contextualiza histórica y socialmente la ciencia. En la enseñanza posibilitó el aprendizaje tanto de elementos conceptuales (célula, clonación, bioética, biodirecto, etc.) como actitud (respeto, organización, etc.) y procedimentales (realizar una investigación, construir argumentos, etc.) de manera más participativa.

PALABRAS-CLAVE: Enseñanza de Biología. PIBID. Historia de la Ciencia. La clonación.

\section{INTRODUÇÃO}

No escopo das políticas realizadas pelo governo federal para melhorar/valorizar a formação de professores foi criado em 2007 o PIBID (Programa Institucional de bolsas de Iniciação à Docência). De acordo com Gatti et al (2014) a criação do programa intencionou "fomentar a iniciação à docência com a finalidade de melhor qualificá-la, mediante projeto específico de trabalho e concessão de bolsas, abrangendo as diferentes áreas do conhecimento que fazem parte do currículo da educação básica" (p.09).

No site oficial do PIBID (http://www.capes.gov.br/educacao-basica/capespibid/pibid) os sete objetivos elencados incluem desde a valorização do magistério até a integração universidade escola (BRASIL, 2018). Um dos objetivos relacionados a formação inicial de professores e que vale destacar aqui está o de:

inserir os licenciandos no cotidiano de escolas da rede pública de educação, proporcionando-lhes oportunidades de criação e participação em experiências metodológicas, tecnológicas e práticas docentes de caráter inovador e interdisciplinar que busquem a superação de problemas identificados no processo de ensino-aprendizagem (n/p).

Entendemos que o PIBID tem muitas possibilidades, mas há limites, principalmente na esfera macro, se considerarmos que é um programa que traz "os reflexos de políticas imediatistas, assistencialistas" (MEDEIROS e PIRES, 2014) e que muitas vezes seus fundamentos baseados em propostas da "pedagogia da prática", podem afastar os sujeitos envolvidos de reflexões mais criticas sobre a proposta.

É importante esclarecer que os aspectos metodológicos não fazem sentido se descolados da discussão relacionada aos "sentidos" da escola (papel social) e dos conteúdos lá discutidos, porém, os aspectos metodológicos se constituem os caminhos pelos quais os objetivos formativos da escola podem se materializar. 


\section{REFERENCIAL TEÓRICO}

Um dos caminhos pensados nessa proposta está relacionado a uma abordagem centrada na História e Filosofia da Ciência (HFC). Para Nascimento Jr, Souza e Carneiro (2011) ao pensar uma contextualização história e filosófica da ciência "centra-se na compreensão de que a realidade é historicamente construída, e o conhecimento científico faz parte dessa construção" (p. 225). Assim, para os autores, é necessário que "o conhecimento científico ao ser ensinado explicite o caminho de sua construção, não sendo compreendido como meramente instrumental, mas um componente essencial para a leitura e crítica da realidade multifacetada" (p. 225). Para Matthews (1995), a HFC não tem todas as respostas, mas pode:

humanizar as ciências e aproximá-las dos interesses pessoais, éticos, culturais e políticos da comunidade; podem tomar as aulas de ciências mais desafiadoras e reflexivas, permitindo, deste modo, o desenvolvimento do pensamento crítico; podem contribuir para um entendimento mais integral de matéria científica, isto é, podem contribuir para a superação do mar de falta de significação que se diz ter inundado as salas de aula de ciências, onde fórmulas e equações são recitadas sem que muitos cheguem a saber o que significam; podem melhorar a formação do professor auxiliando o desenvolvimento de uma epistemologia da ciência mais rica e mais autêntica, ou seja, de uma maior compreensão da estrutura das ciências bem como do espaço que ocupam no sistema intelectual das coisas (p. 165).

Em síntese, consideramos que inserir a HFC no ensino de ciências, como abordagem é contextualizadora, pois contribui para dar sentido à Ciência podendo trazer para o ensino os contextos ético, social, histórico, filosófico e tecnológico envolvidos na atividade científica (NASCIMENTO JR, SOUZA e CARNEIRO, 2011). Ainda para os autores, sem desvalorizar a importância da observação, experimentação, argumentação racional, ceticismo, etc na ciência, uma abordagem a partir da HFC permite discutir a "falácia da neutralidade do conhecimento" (226).

Atrelado a essa abordagem entendemos que o uso do cinema em sala de aula pode contribuir com o ensino-aprendizado de biologia. No Brasil, muitos relatos dessa utilização foram publicados e, sem fazer julgamentos ou analises qualitativas, destacamos os relatos de experiência de Santos e Aquino (2011); Barros, Girasole e Zanella (2013); Maestrelli e Ferrari (2006) e suas experiências com a utilização de cinema no ensino de ciências (química e biologia).

Napolitano (2006) indica que são muitas as contribuições do uso do cinema para o ensino, incluindo aí o de biologia. Para o autor, entre elas, esse uso pode permitir a criação de um olhar crítico sobre a ciência, olhar que é derivado da observação dos aspectos históricos, sociológicos e da visão de ciência apresentados nesses filmes. Ainda na relação do cinema 
com a abordagem da HFC apresentada neste estudo, Carvalho (1998) indica que as imagens do cinema são preenchidas de historicidade permitindo,

a compreensão de como os homens constroem a vida social, uma vez que estes expressam, e deixam registrados para a posteridade, práticas sociais, modos de pensar, valores, símbolos, sentimentos, comportamentos, tensões, expectativas, temores, próprios de uma determinada sociedade. Abrem, assim, novas perspectivas para que o homem conheça seu momento histórico, sua relação com outros homens, o como e o porquê os homens se educam, subsidiando a reconstrução histórica do objeto educação (p.122).

Porém, mesmo levantando às possibilidades, Napolitano (2006) deixa claro que o uso do cinema não vai resolver a crise no ensino escolar (incluindo o ensino de ciências) e nem substituir o desinteresse pela palavra escrita.

Assim, pensando na HFC como caminho/estratégia tanto para formação de professores, via PIBID, quanto para o ensino de ciências na escola é que se situou a proposta aqui apresentada. O objetivo deste artigo foi então socializar e discutir criticamente uma sequência didática realizada por um bolsista de iniciação á docência (ID) no contexto do PIBID que utilizou o cinema (filmes comerciais) para problematizar historicamente o tema clonagem (em especial a clonagem humana).

\section{MATERIAIS E MÉTODOS}

Para organizar o relato e discussão ora apresentado entendemos ser importante contextualizar o locus no qual essa atividade foi pensada e desenvolvida. Assim, apresentamos inicialmente o PIBID e a escola parceira, posteriormente descrevemos e discutimos a sequência didática desenvolvida para o ensino de clonagem no Ensino Médio.

a) O PIBID Biologia

O projeto PIBID Biologia ao qual a atividade apresentada está relacionada foi submetido ao edital 061/2013 (CAPES) e teve início em 2014. Trata-se de um subprojeto de uma instituição de ensino superior pública (federal) localizada no estado de Goiás. Considerando que os professores em formação são pouco apresentados às questões epistemológicas, históricas e sociais da ciência o objetivo geral da proposta do PIBID Biologia em questão foi desenvolver com os bolsistas, ações junto à escola que discutissem a HFB (História e Filosofia da Biologia) no ensino da ciência a partir de atividades práticas. No contexto deste PIBID, essa abordagem possibilitaria uma discussão mais ampla acerca da atividade científica e a compreensão de que a realidade é historicamente construída fazendo a ciência parte dessa construção. $\mathrm{O}$ trabalho aqui apresentado foi realizado por um bolsista de Iniciação à Docência (de um total de 21 estudantes) ingressante no programa em 2017, supervisionado 
por um dos quatro supervisores vinculados ao projeto e orientado por uma das duas coordenadoras da subárea do PIBID Biologia da instituição.

b) A Escola Parceira e a Turma do $1^{\circ} \mathrm{F}$ do Ensino Médio

Desde o seu início o PIBID Biologia aqui apresentado funciona em uma escola pública estadual da periferia de Goiânia (GO). A escola atende aproximadamente 1200 alunos distribuídos em três turnos (matutino/vespertino/noturno) e em turmas que vão do ensino fundamental II ( $6^{\circ}$ ao $9^{\circ}$ ano) até o ensino médio. Como característica especifica é uma escola que tem sua gestão militarizada desde o segundo semestre de 2015. As aulas de Biologia são ministradas por 3 (três) professores que são também os supervisores do PIBID Biologia desde 2014. No turno matutino são 7 (sete) turmas de $1^{\circ}$ ano (A até $G$ ), porém, em função do horário da escola e do Pibidiano que desenvolveu a atividade, a sequência aqui apresentada foi desenvolvida no $1^{\circ}$ ano $\mathrm{F}$. Essa turma era composta por aproximadamente 40 estudantes .

c) A atividade desenvolvida

A sequência didática aqui apresentada foi realizada durante 5 (cinco) encontros de 90 minutos cada um. Antes dessa sequência (Quadro 1) a professora supervisora já havia ministrado uma aula sobre célula a partir da História da Ciência (HC). Os filmes que fizeram parte da sequência foram: Interestrelar (Direção: Christopher Nolan; EUA, 2014) e A ilha (Direção: Michael Bay; EUA, 2005).

Quadro 1: Sequência Didática Elaborada e Desenvolvida

\begin{tabular}{|c|c|c|c|c|}
\hline Aula & Tempo & Objetivo & Conteúdos & Atividade \\
\hline 1 & $90 \mathrm{~min}$ & $\begin{array}{l}\text { - Compreender a ciência } \\
\text { como uma construção } \\
\text { humana historicamente } \\
\text { situada; } \\
\text { - Revisar conceitos de } \\
\text { física, química e biologia } \\
\text { de maneira contextual; }\end{array}$ & $\begin{array}{l}\text { - A ideia de Ciência; } \\
\text { - O uso social da ciência } \\
\text { (financiamento } \\
\text { desenvolvimento); } \\
\text { - Revisão de alguns conteúdos } \\
\text { de ciências como: a) Física: o } \\
\text { Vácuo e gravidade da terra; b) } \\
\text { Química: o papel do } \\
\text { nitrogênio para vida; c) } \\
\text { Biologia: Célula (óvulo) e } \\
\text { fertilização; Características } \\
\text { gerais dos tardigrados; fata de } \\
\text { gravidade e atrofia muscular. }\end{array}$ & $\begin{array}{l}\text { Projeção do filme } \\
\text { "Interestrelar" e } \\
\text { entrega de roteiro } \\
\text { com questões } \\
\text { problematizadoras } \\
\text { sobre o filme. }\end{array}$ \\
\hline 2 & $90 \mathrm{~min}$ & $\begin{array}{l}\text { - Discutir a produção } \\
\text { cientifica e o acesso a ela } \\
\text { pela população; } \\
-\quad \text { Analisar os } \\
\text { determinantes e conflitos } \\
\text { éticos e morais da } \\
\text { clonagem apresentada no }\end{array}$ & $\begin{array}{l}\text { - } \mathrm{O} \text { acesso à ciência numa } \\
\text { sociedade desigual; } \\
\text { - O conceito de clone e os } \\
\text { diversos tipos de clonagem } \\
\text { (vegetal/animal/humana); } \\
\text { - Clonagem Animal (O caso }\end{array}$ & $\begin{array}{l}\text { Projeção do filme } \\
\text { "A ilha" e entrega } \\
\text { de roteiro com } \\
\text { questões } \\
\text { problematizadoras }\end{array}$ \\
\hline
\end{tabular}




\begin{tabular}{|c|c|c|c|c|}
\hline & & $\begin{array}{l}\text { filme } \text { A ilha; } \\
\text { - Discutir os diversos } \\
\text { tipos de clonagem com } \\
\text { foco no caso da ovelha } \\
\text { Dolly; }\end{array}$ & $\begin{array}{l}\text { da ovelha Dolly); } \\
\text { - Bioética e biodireito. }\end{array}$ & sobre o filme. \\
\hline 3 & $90 \mathrm{~min}$ & $\begin{array}{l}\text { - Problematizar o contexto } \\
\text { apresentado pelo filme } A \\
\text { ilha fazendo um paralelo } \\
\text { com a ciência na } \\
\text { atualidade; } \\
\text { - Discutir a clonagem } \\
\text { humana do ponto de vista } \\
\text { biológico, ético e moral; }\end{array}$ & $\begin{array}{l}\text { - O papel social da ciência; } \\
\text { - Os determinantes biológicos, } \\
\text { éticos e morais da clonagem } \\
\text { humana; }\end{array}$ & Debate mediado \\
\hline 4 & $90 \mathrm{~min}$ & $\begin{array}{l}\text { - Apresentar a } \\
\text { possibilidade tecnológica } \\
\text { para o desenvolvimento } \\
\text { da clonagem humana; } \\
\text { - Estimular a elaboração } \\
\text { de argumentos críticos } \\
\text { para defesa de ponto de } \\
\text { vista sobre clonagem; } \\
\text { - Possibilitar a construção } \\
\text { de atitudes como - } \\
\text { respeito as regras; respeito } \\
\text { á fala dos colegas; } \\
\text { trabalho em grupo; etc }\end{array}$ & $\begin{array}{l}\text { - Clonagem Humana } \\
\text { (possibilidade biológica e } \\
\text { tecnológica) } \\
\text { - Implicações éticas da } \\
\text { clonagem humana; } \\
\text { - Construção de argumentos } \\
\text { prós e contras relacionado a } \\
\text { clonagem humana; }\end{array}$ & $\begin{array}{l}\text { Realização de Júri } \\
\text { Simulado }\end{array}$ \\
\hline 5 & $90 \mathrm{~min}$ & $\begin{array}{l}\text { - Compreender o percurso } \\
\text { lógico/histórico } \\
\text { funcional dos estudos de } \\
\text { clonagem (terapêutica e } \\
\text { reprodutiva), } \\
\text { evidenciando a construção } \\
\text { de conceitos, técnicas, } \\
\text { ferramentas e práticas } \\
\text { experimentais; } \\
\text { - Refletir sobre } \\
\text { perspectivas futuras } \\
\text { levando em conta os } \\
\text { avanços da biotecnologia, } \\
\text { biologia molecular e } \\
\text { celular, além de meditar } \\
\text { nos princípios de valores } \\
\text { morais que colidem com o } \\
\text { tema. }\end{array}$ & $\begin{array}{l}\text { - Clonagem terapêutica e } \\
\text { clonagem humana; } \\
\text { - Célula tronco e Célula } \\
\text { embrionária; } \\
\text { - Técnicas de transferência } \\
\text { nuclear; sistemas modelos; } \\
\text { diferenciação; } \\
\text { desdiferenciação } \\
\text { transdesdisferenciação. } \\
\text { - Projeções futuras de } \\
\text { trabalhos com clonagem; } \\
\text { implicações do ponto de vista } \\
\text { ético, moral e religioso. }\end{array}$ & $\begin{array}{l}\text { Aula expositiva } \\
\text { dialogada }\end{array}$ \\
\hline
\end{tabular}

Fonte: Elaboração dos autores 


\section{ANÁLISE DOS DADOS E RESULTADOS}

Como dito anteriormente a atividade foi desenvolvida no contexto do PIBID Biologia de uma universidade federal do estado de Goiás por um bolsista de iniciação em docência recémingresso no programa. O referido PIBID está organizado formativamente da seguinte maneira: a) Encontro formativo coletivo (uma vez por semana): nesses momentos os alunos discutem coletivamente com supervisores e coordenadores de área questões teóricas (a partir da leitura de livros e artigos) que fundamentam a proposta que será desenvolvida na escola; b) Horário de Elaboração de Atividades (duas vezes na semana): nesses momentos, individualmente ou em pequenos grupos (duplas ou trios) os alunos se organizam para pensar e preparar as atividades que serão desenvolvidas na escola; c) Desenvolvimento das atividades na escola (uma ou duas vezes na semana): nesses momentos os alunos acompanham uma turma durante um semestre letivos com a supervisão permanente do professor. Nesse momento os pibidianos desenvolvem o que foi preparado e avalia a estratégia em questão, refletindo, a luz dos referenciais teóricos utilizados as contribuições e os limites da proposta.

O relato se limita aqui a etapa de atuação do pibidiano na escola, sem discussões sistemáticas sobre as etapas de fundamentação teórica e de preparação das atividades. Sendo assim, na escola parceira a atividade, como dito anteriormente, foi desenvolvida em uma turma do $1^{\circ}$ ano do ensino médio que era composta por aproximadamente 40 (quarenta) alunos. A estrutura da sala delimitava, com certo desconforto, essa quantidade de estudantes. O pequeno tamanho somado ás dificuldades de climatização (janela pequena, ventiladores ruins e ar condicionado quebrado) gerava inquietação para além daquela normal para a idade. Consideramos que é importante discutir a escola pública não apenas nos seus problemas pontuais (falta disso ou falta daquilo), mas entender que essa falta retrata uma política de educação que nunca priorizou a escolarização da população que necessita obter seu aprendizado em um ambiente escolar público.

Em relação ao conteúdo desenvolvido, segundo o próprio currículo referência da escola parceira, os alunos do $1^{\mathrm{o}}$ ano do Ensino Médio estudam, ao longo do ano, os seguintes eixos temáticos: a) Origem da vida (compreendendo os conteúdos de base molecular da vida, constituinte da água, origem da vida na terra e as teorias modernas sobre a teoria da vida na terra); b) Identidade dos seres vivos (com os conteúdos de morfologia e fisiologia celular, metabolismo energético, divisão celular, tipos de reprodução dos seres vivos, reprodução humana, desenvolvimento embrionário humano e comparado, histologia animal e vegetal). Esses assuntos são distribuídos ao longo de quatro bimestres. Não obstante, em virtude desta vasta dimensão de conteúdos, e para efeito de definição de parâmetros a serem desenvolvidos com a turma, optamos por trabalhar com a discussão sobre a célula (via a discussão sobre clonagem) visto sua importância e expressão, para a espécie humana, pois, é a célula á unidade morfofisiológica básica de todo ser vivo. 
Já sabendo a série do ensino médio e os eixos temáticos, o próximo passo na escola consistia na apresentação do bolsista ID e da proposta inicialmente pensada aos estudantes. Muitos alunos da escola ainda não sabiam o que era o PIBID e ficaram muito interessados em ouvir a história, os objetivos e a participação dos bolsistas do PIBID na dinâmica escolar. As explicações sobre à sequência didática foi apresentada pelo bolsista juntamente com a supervisora. Os objetivos formativos foram esclarecidos e a dinâmica com os filmes pareceu ter agradado muito. Foi gratificante observar que mesmo com a inquietação inicial no final os estudantes da turma pareceram motivados com a proposta e em aprender os conteúdos escolhidos.

Superar o modelo transmissão-recepção nunca é fácil, pensar em estratégias que realmente contribuam para que os alunos possam aprender conteúdos que façam sentido e contribuíram para desenvolver uma "outra leitura" do mundo foi o desafio. Atrelado a isso, o desafio maior é que a atividade seria desenvolvida por um professor em formação, ainda inexperiente na docência.

Como já indicado, o tema escolhido á clonagem que tem relação direta com a teoria celular ${ }^{1}$. É importante destacar que célula é um conceito chave dentro da biologia por ser essa a unidade que caracteriza a vida. Para Nascimento Jr e Souza (2016) foi ideia de célula permitiu unificar todos os seres vivos, assim, podemos afirmar ser esse um conceito estrutural. Ainda para os autores (apud Aduriz-Bravo et ali, 2002) as ideias estruturantes são "conceitos disciplinares capazes de organizar teoricamente os distintos conceitos e modelos presentes no currículo. Neste sentido, se trata dos eixos direcionadores da organização sintática e curricular de uma área específica de conhecimento" (p.59). Já um desdobramento desse conceito está no conceito de clonagem. A discussão sobre clonagem envolve muitos conceitos tanto da teoria celular quanto da teoria da herança, porém, aqui serão mais destacadas relações com a discussão celular e menos com a genética.

Também como dito anteriormente optamos por trabalhar com a utilização de ferramentas audiovisuais no ensino de biologia. Essa opção poderia, no nosso caso, aproximar os alunos da ciência a partir de uma linguagem mais "conhecida" bem como apresentar as relações da ciência com a sociedade numa perspectiva sócio-histórica a partir dos contextos dos filmes. Trazer a biologia e seus conceitos associados a outros aspectos sociais como as relações econômicas, políticas, éticas, etc é um potencial dessa relação.

Em vista disso, foram escolhidos dois filmes. O primeiro chamado Interestelar do diretor Christopher Nolan (EUA, 2014) consiste em aventura, drama e ficção científica. Sua sinopse é a seguinte:

\footnotetext{
${ }^{11}$ Nascimento Jr, Souza e Carneiro (2011) indicam que cinco grandes teorias estruturam a biologia enquanto ciência, a Teoria Celular, a Teoria da Herança, a Teoria da Homeostase, a Teoria da Evolução e a Teoria Ecológica.
} 
Após ver a Terra consumindo boa parte de suas reservas naturais, um grupo de astronautas recebe a missão de verificar possíveis planetas para receberem a população mundial, possibilitando a continuação da espécie. Cooper é chamado para liderar o grupo e aceita a missão sabendo que pode nunca mais ver os filhos. Ao lado de Brand, Jenkins e Doyle, ele seguirá em busca de uma nova casa. Com o passar dos anos, sua filha Murph investirá numa própria jornada para também tentar salvar a população do planeta (http:/www.adorocinema.com/filmes/filme-114782/)

Na nossa avaliação, por ser esse filme plural do ponto de vista cientifico/filosófico, isto é, apresentar conhecimentos de caráter biológico, físico, químico e filosófico, foi considerado uma escolha com potencial para uma discussão sobre a ciência e suas intencionalidades e não neutralidades. Além de assistir o filme, os alunos receberam uma lista de questões referente ao próprio filme. Ao todo foram dez questões discursivas, sendo que as cinco primeiras abordavam passagens do filme e as cinco últimas problematizavam a ciência e seus aspectos conceituais e sócio-históricos. As perguntas levantavam problemas conceituais que questionavam: seria possível (do ponto de vista biológico) a vida em outro planeta? Que condições as células precisariam para sobreviver? E sócio-históricas do tipo: quem financia a ciência? Quem a produz? Qual sua importância social? Quem tem acesso a ela? Sempre foi assim? Entre outras. Para Nascimento Jr, Souza e Carneiro (2011) essas questões são importantes, pois se compreendemos a Ciência como atividade humana que resulta em "conhecimento sistematizado, construído, avaliado e validado intersubjetivamente e objetivamente a partir de valores e regras compartilhados em determinados contextos históricos" (p.225) precisamos de um ensino que supere a transmissão de informações/ conceitos descontextualizados. Para essa superação a inserção da HFC no ensino de ciências pode contribui para o resgate do sentido social da Ciência.

No final da projeção, os alunos pareciam bem interessados e entusiasmados. A lista de questões começou a ser resolvida, e depois de finalizada, foi entregue para o bolsista ID. Pela inexperiência do professor bolsista a lista perecia inicialmente uma opção mais adequada do que a mediação de um debate naquele momento. Porém, na avaliação final da sequência talvez fosse mais interessante um debate naquele momento. As listas foram corrigidas pelo bolsista ID que percebeu que os alunos realizaram leituras paralelas (nos celulares) com a finalidade de aprimorar suas respostas e quase todos atingiram o que era esperado nos objetivos propostos. Nesse sentido, apesar de alguma dificuldade de escrita, percebemos que ao longo das questões propostas, os alunos obtiveram maior desempenho nas questões referentes ao plano reflexivo (relações sócio-históricas), e os professores (bolsista ID e supervisora) consideraram que as respostas foram de alto nível de competência no sentido de que faziam muitas relações conceituais e relacionavam a temática com questões morais (de cunho religioso). Vale salientar que, a resolução das outras questões, do filme propriamente dito, também foram bem feitas, mostrando a atenção que o grupo dedicou aos detalhes do filme. 
Após a conclusão da primeira atividade, o segundo filme escolhido deveria trabalhar mais diretamente com os assuntos que a turma estava estudando, ou seja, o conteúdo de células, especialmente os ácidos nucleicos (clonagem). Nesse sentido, o filme $A$ Ilha do diretor Michael Bay (EUA, 2005) pareceu uma boa opção. Na sinopse observamos a seguinte descrição:

No futuro existe uma entidade utópica baseada na vida do século XX, que procura recriá-la nos mínimos detalhes. Lincoln Six Echo vive nesta realidade e, como todos seus residentes, sonha em chegar em um local chamado "a ilha", o único ponto não contaminado do planeta. Após descobrir que todos os habitantes são clones, que possuem a única finalidade de fornecer partes de seu corpo para seres humanos reais, Lincoln decide escapar juntamente com Jordan Two Delta (http://www.adorocinema.com/filmes/filme-55792/)

Vale ressaltar que esse filme não trabalha especificamente com os conceitos de células e ácido nucleicos, mas sim com o tema clonagem, especialmente clonagem humana. Porém, para a compreensão da clonagem é necessário que o estudante compreenda os aspectos morfofisiológicos básicos da célula. O filme poderia potencializar, no nosso entendimento, novamente as discussões sobre questões sociais da ciência com ênfase nas questões éticas. Elementos da Biologia celular, molecular e biotecnologia também poderiam ser discutidos com esse filme.

O filme foi projetado em sala de aula, os estudantes assistiram na íntegra, e logo após foi entregue a lista de questões para a turma (semelhante a do filme Interestelar) para que eles realizassem em suas casas e entregassem na próxima aula. Percebemos que o contato dos alunos com filme em sala foi mais impactante do que o do primeiro filme, muito em virtude do próprio caráter do filme. O cenário fictício mais atraente, o suspense formado no início do filme e o desenvolvimento apresentando a temática clonagem implicaram várias inquietações na turma no sentido ético e moral. Exemplo disso foram os comentários dos alunos após o término do filme, perguntas como: "E se isso acontecer mesmo entre nós?", "E se criarem um clone de mim? Ele teria os mesmos direitos do que eu?" começaram a ser socializadas. Porém, como o filme era longo e acabou junto com a aula esses levantamentos ficaram para o debate.

$\mathrm{Na}$ terceira aula foi realizado um debate sobre o filme $A$ ilha. Esse debate foi mediado pelo bolsista ID com a supervisão da professora da turma. O debate teve início com uma breve síntese do filme e com a problematização dos aspectos bioéticos e religiosos envolvidos na história. O assunto que mais surgia, independente do encaminhamento realizado pelo bolsista, estava relacionado á possibilidade da concretização da realidade apresentada no filme - a criação de clones humanos. Aspectos mais conceituais relacionados à clonagem só apareceram quando levantados na mediação do bolsista e perguntas mais controversas como: "Os cientistas de hoje brincam de Deus?"; "Será que Deus tem algum significado nesse 
contexto?" insistiam em surgir. Nesse momento o debate foi redirecionado para questões que envolviam ciência e ética. Esse redirecionamento aconteceu para que, mesmo de forma indireta, não ferisse os credos, ritos e valores daquele aluno que trás uma forte bagagem religiosa.

Fazendo uma análise geral percebemos que a turma apresentou uma participação excelente, se envolvendo com a proposta e entendendo a clonagem (aspectos conceituais) seu desenvolvimento e as questões relacionadas ao domínio da técnica e as implicações éticas do seu desenvolvimento (histórico-social). No final o bolsista e a supervisora fizeram um resumo do filme e dos elementos levantados pelos estudantes durante o debate. Antes da aula acabar as listas de questões foram recolhidas.

Novamente o bolsista ID levou as questões para analisar e percebemos que os bons argumentos levantados no debate também estiveram presentes na resolução das questões. $\mathrm{O}$ nível argumentativo dos alunos cresceu se considerarmos como parâmetro inicial a lista do filme anterior. Sobretudo nas questões de cunho reflexivo e nas que exigiam uma análise mais crítica sobre ciência (no caso a clonagem) e seu impacto na sociedade. Diante disso, percebemos que a turma já estava avançada, no sentido de familiarização com a temática clonagem e, nesse sentido, pronta para participarem de outro degrau do planejamento, isto é, o trabalho com o júri simulado.

A escolha do júri simulado se justifica por ser o tema - clonagem humana algo polêmico e que diverge opiniões e, sendo assim, bastante coerente com a forma pela qual iriamos trabalhar. Outro ponto importante, a turma gostou da ideia quando a sequência didática foi apresentada inicialmente. A professora supervisora ficou responsável de explicar como funcionaria esse trabalho, dividiu os grupos e propôs que estudassem para defenderem seu lado, ou seja, o lado contra e a favor da clonagem humana.

Assim, na quinta aula da sequência didática, os alunos dividiram-se em dois grandes grupos (contra e a favor a clonagem humana) que ficaram nas extremidades da sala, o bolsista ID que mediou o debate ficou no meio. A discussão foi iniciada com mediador levantando as seguintes questões: a) A clonagem humana é possível do ponto de vista das técnicas atuais? b) Ela deveria ser desenvolvida/melhorada e sua utilização possibilitada? Cada grupo tinha então seu momento de fala para defender seu ponto de vista. A defesa não poderia ser por "gosto" ou a partir de ponderações ingênuas, mas deveriam explicitar argumentos baseados em fatos. O júri começou bem, mas em virtude do tema e da sua polêmica em alguns momentos o clima "esquentou" e as discussões foram mais contundentes. Em alguns momentos percebemos a dificuldade dos estudantes em aceitar o argumento do outro sem contra argumentações pessoais. Porém, ao longo do júri o mediador prezou pela ordem e respeito e reorientou a discursão quando necessário. Isso foi aprendizado tanto para o professor em formação (aprender a conduzir) quando para os alunos (aprender a respeitar o outro). 
O júri simulado, em linhas gerais, foi concretizado com sucesso. Os argumentos, tanto prós como contra a clonagem humana, envolveram novamente aspectos bioéticos, a dimensão do biodireito, o plano religioso bem como historias e exemplos bons e ruins relacionados ao tema em questão. Foi possível considerar que, desde a organização até o nível argumentativo, a atividade gerou aprendizagem tanto de elementos conceituais (célula, clonagem, bioética, biodireito, etc) quanto atitudinais (respeito, organização, etc) e procedimentais (realizar uma pesquisa, construir argumentos, etc) ${ }^{2}$. No final do júri, a professora supervisora, em virtude da qualidade de ambos os grupos, decretou o empate e, logo após, o bolsista ID fez uma breve retomada do assunto sintetizando os pontos ainda em aberto.

Para finalizar a sequência didática planejada foi preparada uma aula expositiva dialogada sobre clonagem. Essa aula foi pensada a partir da abordagem da HFC (como é a proposta do PIBID Biologia em questão). Assim, fundamentados em Nascimento Jr, Souza e Carneiro (2011) a aula procurou mostrar o percurso lógico/histórico do desenvolvimento da ciência (clonagem) e também contribuir para a formação de competências ligadas ao domínio dos conceitos atuais relacionados ao tema. A aula também foi fundamentada em Mayr (2005), pois, considerou o pensar evolutivo que, nesse contexto de clonagem, consistiu em traçar uma linha do tempo pontuando os principais acontecimentos que desencadearam novos estudos, descobertas e aprimoramento de técnicas com células, embriões, material genético, etc. Essa aula apresentou também o contexto de cada época que possibilitou o desenvolvimento de determinados experimentos desde os estudos de Mangold e Spearman ${ }^{3}$ até os estudos atuais. Já para as questões de causas próximas ou funcionais, o bolsista ID trouxe explicações sobre a existência das mais diversas técnicas e metodologias de trabalho de pesquisa, tal como aconteceu na abordagem do experimento com embriões de anuros de Robert Briggs e Thomas King ${ }^{4}$ e mais recente as técnicas que geraram a ovelha Dolly ${ }^{5}$. Também foram

\footnotetext{
2 Antonio Zabala (1995) divide os objetivos educacionais em três: objetivos conceituais, procedimentais e atitudinais. O primeiro está relacionado ao aprendizado de conceitos propriamente ditos como o conceito de clonagem. Os objetivos procedimentais estão relacionados com procedimentos que o aluno possa vir a desenvolver, a manipulação de um microscópio ou a técnica simples de extração de DNA poderiam estar aqui enquadrados. Já os objetivos atitudinais estão relacionados com as ações frente ao tema, a tomada de decisão frente a um tema ou o respeito ao colega num debate podem ser exemplos situados aqui.
}

${ }^{3}$ Hilde Mangold (1898-1924) e Hans Spearman (1869-1941) foram embriologistas que no inicio do século XX isolaram um pequeno pedaço de embrião e o enxertaram em outro. $O$ tecido enxertado foi capaz de organizar as células circundantes no receptor e induzir a formação de um embrião (SHUBIN 2008; GOLDIM, 2003).

${ }^{4}$ Robert Briggs (1911-1986) e Thomas King (1921-2000) foram biólogos que trabalharam com embriões de anuros (sapos) na década de 50 sendo os primeiros a desenvolverem a técnica de transferência nuclear. Através desse mecanismo foi possível a realização dos processos de clonagens em sapos (GOLDIM , 2003).

${ }^{5}$ A ovelha Dolly foi o primeiro mamífero clonado da história, ocorrido na década de 90 nos instituto Roslin na Escócia. Dolly foi gerada a partir da técnica da transferência nuclear, ou seja, foi obtido um óvulo sem núcleo de uma ovelha e de outra ovelha foi extraído o núcleo de uma célula diplóide. Após isso, uniram esses dois elementos com um auxílio de estímulos elétricos e implantaram em uma terceira ovelha que foi a barriga de

\begin{tabular}{l|l|l|l|l|l|l|} 
(C) Rev. Triang. & Uberaba, MG & v.10 & n.2 & p. 28-42 & Jul./Dez. 2017 & ISSN 2175-1609
\end{tabular}


explicados em detalhes os pontos que diferenciam as clonagens reprodutivas e terapêuticas, inclusive, retomando as implicações do ponto de vista ético e moral já levantadas no debate do filme $A$ ilha.

\section{CONSIDERAÇÕES FINAIS}

O PIBID, a despeito de todas as críticas que possa receber como política de formação de professores, no caso do subprojeto apresentado aqui favoreceu uma formação compartilhada entre bolsista ID, supervisor e coordenador de área. Os aspectos relatados de desenvolvimento da atividade mostram que uma parceria mais orgânica escola-universidade é possível. A abordagem relacionada á HFC associada com o uso do cinema também foi uma experiência, tanto de formação docente inicial quando de ensino de ciências (biologia) no ensino médio, bem positiva. Esse aspecto positivo não se limitou a estimular os alunos a aprender por ser mais "legal" ou a possibilitar o bolsista - professor em formação - a elaborar atividades "diferentes".

Do ponto de vista da formação de professores, numa perspectiva mais geral, a atuação na escola, a partir das discussões realizadas no grupo de estudo do PIBID possibilitou entender e discutir a escola e seu papel social de maneira crítica e contextualizada. Percebemos também que a atividade possibilitou estudos mais sistemáticos sobre HFC e assim uma melhor compreensão sobre a natureza da ciência que se ensina (biologia). Embora a materialização no ensino tenha sido centrada muito mais em aspectos históricos do que filosóficos o trabalho ainda assim teve valor. O estudo e desenvolvimento de alternativas de ensino que superem o modelo transmissão-recepção ainda reproduzido na formação de professores nas universidades foi outro ganho formativo. Finalmente, a oportunidade de realizar a gestão dos conflitos em sala de aula, em especial no júri simulado, apoiado por uma professora mais experiente foi um aprendizado também possibilitado nesse contexto formativo.

Em relação ao ensino de biologia para os alunos do ensino médio, destacamos a participação e envolvimento dos estudantes com a proposta. Os alunos estiveram o tempo todo ativos e a interação possibilitou discussões ricas do ponto de vista teórico. A apreensão dos conteúdos biológicos na sua relação com os determinantes sócio-históricos também foi considerada boa na avaliação da atividade. Finalmente, pode ser considerada uma contribuição positiva o estimulo à construção de uma postura crítica e reflexiva por parte dos alunos diante de um tema controverso como a clonagem.

aluguel de Dolly. Dolly foi sacrificada após 6 anos de idade em razão de apresentar grandes problemas nas articulações além de problemas respiratórios (WIKIPEDIA, 2018). 


\section{REFERÊNCIAS}

BARROS, M. D. M. de; GIRASOLE, M.; ZANELlA, P. G. O uso do cinema como estratégia pedagógica para o ensino de ciências e de biologia: o que pensam alguns professores da região metropolitana de Belo Horizonte. Revista Práxis, Ano V, n. 10, p.97115. Dez. de 2013. Disponível em: <http://web.unifoa.edu.br/praxis/numeros/10/97115.pdf>. Acesso em: 08 de Jan. 2018.

BRASIL, PIBID (Programa Institucional de bolsas de Iniciação à Docência). Disponível em: $<$ http://www.capes.gov.br/educacao-basica/capespibid/pibid $>$. Acesso em: 08 de Jan. de 2018 .

CARVAlHO, E. J. G. de Cinema, História e Educação. Revista Teoria e Prática da Educação - Revista do Departamento de Teoria e Prática da Educação da Universidade Estadual de Maringá, v. 3, n. 5, p. 121-131. Set/1998. Disponível em: <www.dtp.uem.br/lap/publicacoes/cinema-historia-e-educacao/at_download/file>. Acesso em: 01 de Jan. 2018.

GATTI, B. A.; ANDRE, M. E. D.; GIMENES, N. A. S.; FERRAGUT, L. Um estudo avaliativo do Programa Institucional de Bolsa de Iniciação à Docência (Pibid). Fundação Carlos Chagas, São Paulo: FCC/SEP, 2014. Disponível em: $<$ https://www.capes.gov.br/images/stories/download/bolsas/24112014pibidarquivoAnexado.p df > Acesso: em 01 de Jan. 2018.

GOLDIM, J. R. Clonagem aspectos biológicos e éticos. Disponível em: $<$ https://www.ufrgs.br/bioetica/clone.htm> Acesso em: 01 de Jan. 2018.

MAESTRELI, S. R. P. e FERRARI, N. O Óleo De Lorenzo: O uso do cinema para contextualizar o ensino de genética e discutir a construção do conhecimento científico.

Genética na Escola. v. 1, n. 02, p. 35-40, 2006. Disponível em: $<$ http://www.geneticanaescola.com.br/volume-1---n-2>. Acesso em: 01 de Jan. 2018.

MAYR, E. Isto é Biologia: ciência do mundo vivo. São Paulo: Companhia das Letras, 2005. MATTHEWS, M. História, filosofia e ensino de ciências: a tendência atual de reaproximação. Caderno Catarinense de Ensino de Física, v. 12, n. 3, p. 164-214. 1995. Disponível em: < $<$ https://periodicos.ufsc.br/index.php/fisica/article/view/7084> Acesso em: 20 Dez. 2017. 
MEDEIROS, J. L., PIRES, L. L. A., O Pibid no bojo das políticas educacionais de formação de professores, Cadernos de Pesquisa, São Luís, v. 21, n. 2, mai./ago, p. 37-51. 2014. Disponível

em:

$<\underline{\text { http://www.periodicoseletronicos.ufma.br/index.php/cadernosdepesquisa/article/view/2571 }}$

> Acesso: em 01 de Jan. 2018.

NASCIMENTO JÚNIOR, A. F. e SOUZA, D. C. A busca das ideias estruturantes da biologia na história do estudo dos seres vivos no século XIX. Theoria - Revista Eletrônica de Filosofia Faculdade Católica de Pouso Alegre, v.8, n. 19, p. 58-88 2016. Disponível em: $<$ http://www.theoria.com.br/edicao19/04012016RT.pdf> Acesso em: 20 de Dez. 2017.

NASCIMENTO JÚNIOR, A. F.; SOUZA, D. C. de; CARNEIRO, M. C. O conhecimento biológico nos documentos curriculares nacionais do ensino médio: uma análise histórico filosófica a partir dos estatutos da biologia. Investigações em Ensino de Ciências, v. 16, n. 2, p. 223-243 2011. Disponível em:

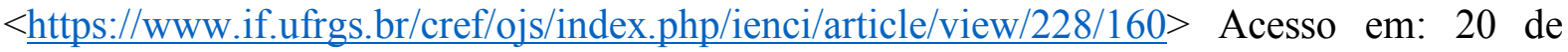
Dez. 2017.

NAPOLITANO, M. Como usar o cinema na sala de aula. São Paulo: Contexto, 2006.

SANTOS, P. N. dos e AQUINO, K. A. da S. Utilização do Cinema na Sala de Aula: Aplicação da Química dos Perfumes no Ensino de Funções Orgânicas Oxigenadas e Bioquímica. Química Nova na Escola. v. 33, n. 3, p.160-167, Agosto 2011. Disponível em:

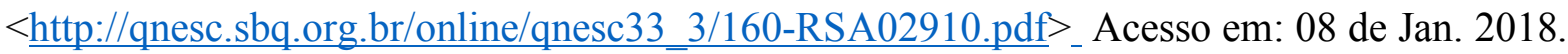
SHUBIN, N. A história de quando éramos peixes: uma revolucionaria teoria sobre a origem do corpo humano. Campus Elsevier: Rio de Janeiro, 2008.

WIKIPEDIA, A Ovelha Dolly. Disponível em: $<$ https://pt.wikipedia.org/wiki/Ovelha_Dolly $>$ Acesso em: 08 de Jan. 2018.

ZABALA, A. Prática educativa: como ensinar. Artmed: Porto Alegre, 1998. 